\title{
Progress in the Biological Exploration of Caves and Subterranean Waters in Israel
}

\author{
By I. Friedmann ${ }^{1}$ )
}

In the past few years, activity increased in the biological exploration of caves and subterranean waters of Israel. Several groups of cave inhabiting plants and animals have been investigated und their taxonomy and morphology as well as their ecology were studied. In the following, a short survey is given of the progress of cave biology in Israel, both of published results and of current projects.

\section{Botany}

Algae

The caves in which algal growth of the rocks was studied are, as many other caves in Israel, shallow and dry. Most of them have been used in prehistoric or historic times as dwelling or funeral places. In these caves the main ecological factor which controls algal growth seems to be humidity while light which generally penetrates these caves to various degrees (e.g. through man-made light shafts in the caves of the Beit Guvrin area) is probably not a limiting factor.

The majority of the algae, both in quantity and in number of species are, as can be expected, blue-greens, occasionally intermixed with diatoms and unicellular green algae. Less usual is the occurrence of a red alga (Phragmonema) and a coccoid Cryptophycean (?) organism (Cyanidium). Some of these algae have been the subjects of separate studies.

Geitleria calcarea Friedmann was described from the Beit Guvrin caves. The filaments of this aerial blue-green alga are densely incrusted by lime crystals. It forms a whitish, woolly coat on the rocks which resembles the growth of moulds. It may be worth to mention that, in most places, G. calcarea is accompanied by Scytonema Julianum (Kütz.) Menegh., the only other blue-green alga which shares with Geitleria its lime-incrusted aerial filamentous habit and its characteristic woolly appearence. Their anatomical organization being entirely different,

1) Department of Botany, The Hebrew University, Jerusalem, Israel. 
the two organisms constitute an example of remarkable ecological parallelism (Friedmann 1955).

Phragmonema sordidum Zopf is a bangioid red alga of rare occurrence, known in Europe mainly from greenhouses. In some caves of Beit Guvrin and in Jerusalem it grows copiously and in these localities sufficient material could be collected for a study of the unusual morphological variability of this organism (Friedmann 1956).

Chroococcidiopsis Kashaii Friedmann, an endospore-forming unicellular blue-green alga was described from a cave in Beit Guvrin. Developmental studies in this organism and in the other two species of the genus Chroococcidiopsis yielded some data for phylogenetical considerations concerning the orders of Myxophyceae (Friedmannn 1961).

The ecology of $C$. Kashaii was studied in several caves. The occurrence of the alga seems to be bound to the presence of nitrates in the substratum. In one of the Beit Guvrin caves, the quantity of nitrates was as high as 5.9 p.c. in dry weight of the rocks and in these extreme conditions, $C$. Kashaii is the only algal inhabitant of the cave. In this as in other Beit Guvrin caves, the nitrate is of mineral origin while in the Kabara cave (Mount Carmel), an other locality of C.Kashaii, the presence of nitrates is a result of decomposition of the guano of cavedwelling bats. Beside a high drought-resistence, C. Kashaii shows a tolerance to high osmotic pressures unusual even in blue green algae as in the Beit Guvrin cave with the highest nitrate content any water in the porous rock substratum necessarily forms a concentrated nitrate solution (Friedmann 1962).

Current research is carried out in the Dept. of Botany of the Hebrew University in Jerusalem on a species of Cyanidium, found in several caves and on a Schizothrix sp., isolated in culture from the Beit Guvrin caves. In the Culture Collection of Algae of the same Department, a constant effort is made to isolate aerial cave algae in order to make them available for further studies.

\section{Zoology $\mathbf{y}^{2}$}

\section{Crustaceans}

Zoological research of caves and subterranean waters started earlier than its botanical counterpart. Thus, amoung the blind Crustaceans

2) The data for this compilation have been kindly supplied by Dr. M. Dor, Dr. F. D. Pór, Prof. K. Reich, Prof. H. Steinitz, Prof. O. Theodor, Mr. M. Tsurnamal M. Sc., Dr. Y. Wahrmann. 
known from subterranean waters, the endemic blind prawn Typhlocaris galilea Calman was described in 1909 and its biology too has been studied to some extent early in this century (Annandale, 1911; Annandale and Kemp, 1913). The classical locality of T. galilea is Birket Ali-el-Dhaher near Tabgha (N. of the lake of Galilee), a small, shallow artifical pond which has been covered in recent times by a building. Its brackish, sulfurous water is fed by three main (and other small) springs of different temperatures in one of which $T$. galilea occurs. The biology of this blind prawn still holds some unsolved problems as young animals or females with eggs have never been collected in the well. Presumably, the original population lives in a deeper tract of a subterranean cave which has not been penetrated so far. At present, research is carried out by Mr. M. Tzurnamal (Dept. of Zoology, Hebrew University) on this and other problems of the ecology and biology of $T$. galilea.

The isopod Typhlocirolana steinitzi Strouhal (1961) was described from a well near Haifa (Kfar Atah). A second species of this genus, T. reichi Pór was found in the brackish spring Ein Hakikar, south of Sodom in the depression of the Dead Sea (Pór, 1962a).

Monodella relicta Pór occurs in the Hamei Zohar spring, N. of Sodom. The water of this spring, with a temperature of $31^{\circ} \mathrm{C}$, has a salinity of $56 \mathrm{~g} / \mathrm{l}$. (Pór, $1962 \mathrm{~b}$ ).

A new Bogidiella sp., collected by Dr. Pór in the Ein Hakikar spring, is recently investigated by Prof. S. Ruffo (Verona, Italy).

\section{Ticks}

The relapsing fever associated with caves was investigated by Adler, Theodor and Schieber in 1937. Based on a study of 45 cases, the Spirochete-transmitting tick was identified as Ornithodorus papillipes. Tick parasites of bats were investigated by Theodor and Moscona (1954). Among 21 spp. and subspp., 3 new taxa were described (Nycteribia biloba Theodor and Moscona, Basiliana sp., and B.bathybothyra daganiae Theodor and Moscona). Further cave-inhabiting ticks were reported by Theodor and Costa in 1960:

Ornithodorus tholozani Laboulbène and Mangin was found in a cave near Herzliya and in other caves near Tel Arad., O.lahorensis Neumann in numerous caves in Darajat (near Tel Arad) and O.salahi Hoogstraal in a cave near Herzliya.

\section{Insects}

The insect fauna of caves is relatively less known. Some caveinhabiting Orthoptera were investigated by Chopard (1963). 


\section{Bats}

A list of the bat fauna of Israel (25 spp.) is given in the paper of Theodor and Moscona (1954). A new Pipistrelle bat (Chiroptera pipistrellus) was described from the Negev desert by Harrison (1960).

The taxonomy and biology of the bats of Israel are currently investigated by Dr. M. Dor (Biological Institute, College of Kibbutz Education, Beit Berl).

\section{ZUSAMMENFASSUNG}

Der Artikel befaßt sich mit biologischen Untersuchungen, die in den Höhlen und anderen unterirdischen Ansiedlungen in Israel durchgeführt wurden. Die botanischen und zoologischen Untersuchungen wurden einzeln zusammengefaßt, und eine Bibliographie der biospeleologischen Untersuchungen in Israel steht zur Verfügung.

\section{ABSTRACT}

The article gives an account of the biological works carried out in the caves and other subterranean habitats of Israel. The botanical and zoological investigations are summarized separately and a list of literature dealing with biospeleological research in Israel is supplied.

\section{REFERENCES}

Adper, S., O. Theodor and H. Schieber - 1937: Observations on ticktransmitted human spirochaetosis in Palestine. Ann. Tropical Med. Parasitol. 31: 25-35.

Annandale, N. - 1912: The blind prawn of Galilee. Nature (London) $90: 251$. - and S. Kemp - 1913: The Crustacea Decapoda of the Lake of Tiberias. J. Asiat. Soc. Bengal, n. ser. 9: 241-58.

Calman, W. T. - 1909: On a blind prawn from the sea of Galilee (Typhlocaris galilea g. et sp.n.). Trans. Linn. Soc. London Zool., Ser. 2, 11: 93-7.

Chopard, L. - 1963: Notes sur la faune des Orthopteroides d'Israel (Blattodea, Gryllacridoidea, Gryllodea). Bull. Res. Counc. Israel, $11 \mathrm{~B}$ : 161-71.

Friedmann, I. -1955 : Geitleria calcarea n. gen. and n. sp. A new atmophytic lime-incrusting blue-green alga. Bot. Notiser 108:439-45 (Studies on cave-algae from Israel I).

- 1956: Beiträge zur Morphologie und Formwechsel der atmophytischen Bangioidee Phragmonema sordidum Zopf. Oest. Bot. Ztschr. 103: 613-633 (Studies on cave algae from Israel II).

- 1961: Chroococcidiopsis Kashaii sp.n. and the genus Chroococcidiopsis (Studies on cave algae from Israel III). Oest. Bot. Ztschr. 108: $354-67$.

- 1962: The ecology of the atmophytic nitrate-alga Chroococcidiopsis Kashaii Friedmann (Studies on cave algae from Israel IV). Arch. Mikrobiol. 42 : $42-5$. 
Harrison, D. L. - 1960: A new species of pipistrelle bat (Chiroptera Pipistrellus) from Southern Israel. Durban Mus. Novit. 5: 261-7.

Pór, F. D. - 1962 a: Un nouveau Thermosbeanacée, Monodella relicta n.sp. dans la dépression de la Mer Morte. Crustaceana 3: 304-10.

- 1962 b: Typhlocirolana reichi n.sp., un nouvel Isopode Cirolanide de la dépression de la Mer Morte. Crustaceana 4: 247-252.

Strounal, H. - 1961: Eine neue, ostmediterrane Typhlocirolana-Spezies (Isopoda, Cirolanidae). Ann. Nat. Hist. Mus. Wien 64 (1960) : 245-56.

Theodor, O. and M. Costa - 1960: New species and records of Argasidae from Israel. Observations on the rudimentary scutum and the respiratory system of the larvae of Argasidae. Parasitology 50:365-85.

- and A. Moscona - 1954: On bat parasites in Palestine. I. Nycteribiidae, Streblidae, Hemiptera, Siphonaptera. Parasitology 44: 157-245. 